\title{
SURVEI KINERJA KONEKSI INTERNET DAN KEMAMPUAN INVESTASI WARNET DI YOGYAKARTA
}

\author{
P. Didit Krisnadewara \\ Universitas Atma Jaya Yogyakarta
}

\begin{abstract}
This research tries to measure internet-services rental connection performance and the owner's investment capacity in Yogyakarta. By conducting a field survey, the data obtained then is descriptively analyzed. The analysis shows that internet-services rental industry in Yogyakarta can be classified as small-scale internet services industry with only 1 to 20 unit of personal computers. In addition, the kind of connection used is the wireless $2.4 \mathrm{G} . \mathrm{Hz}$. (54.29\%) with a connectionspeed of 64 k.b.p.s. (51.43\%). Most of the owner (45.05\%) of the internet-services rentals are willing to increase their investment to upgrade the connection performance up to 10 millon rupiahs.
\end{abstract}

Keywords: connection performance, investment capacity, internet, internet-services rental

\section{PENDAHULUAN}

Pengguna internet di Indonesia berdasarkan cara mengakses dibagi menjadi 2 (dua) kategori, yaitu pelanggan internet melalui internet service provider (ISP) dan bukan pelanggan ISP (Suriadinata, 2001). Pelanggan internet melalui ISP adalah pengguna yang mengakses internet dengan menjadi pelanggan tetap. Sedangkan yang bukan pelanggan ISP adalah mereka yang mengakses internet melalui kantor, warung internet (warnet) dan lain-lain.

Sebagian besar pengguna internet di Indonesia mengakses internet melalui warnet. Kondisi ini dapat dimaklumi karena mengakses internet melalui warnet lebih murah. Sejalan dengan meningkatnya jumlah pengguna internet, maka jumlah warnet di Indonesia juga meningkat. Jumlah pengguna internet pada tahun 2001 diperkirakan sebanyak 4,2 juta orang dan pada tahun 2002 diperkirakan terus meningkat (Hendaru, 2002; Indocommercial, 2002). Perkiraan APJII (Asosiasi Pengusaha Jasa Internet Indonesia) pelanggan internet mencapai 1juta orang, sedangkan pengguna internet sekitar 8 juta orang (Anonim, 2002). Sedangkan jumlah warnet pada tahun 2000 berdasarkan data yang bersumber pada www.natnit.net sebanyak 1.151 buah (Suriadinata,2001),

Industri jasa pelayanan bagi pengguna internet yang kemudian dikenal dengan warung internet (warnet) berkembang pesat di Yogyakarta selama 3 tahun terakhir ${ }^{1}$. Jumlah warnet di Yogyakarta diperkirakan pernah hampir mencapai 200 buah. Sejalan dengan perkembangan dan persaingan dalam industri, jumlah warnet diperkirakan tinggal 170 warnet. Dari jumlah tersebut, 70 warnet diantaranya merupakan anggota AWAYO (Asosiasi Warnet Yogyakarta) ${ }^{2}$. Menurut informasi di lapangan ada beberapa warnet yang terpaksa menutup usahanya karena tidak mampu bersaing, terutama dalam meningkatkan teknologi koneksi jaringan (Anonim, 2001).

Persaingan dalam industri warnet semakin ketat. Hal tersebut dapat dilihat dari jumlah internet di lokasi yang dianggap strategis semakin banyak dan terjadi persaingan dengan menggunakan variabel harga. Tarif per jam semakin kompetitif, dan ada kecenderungan terjadi

${ }^{1}$ Di samping warnet juga dikenal istilah internet café.

${ }^{2}$ Hasil wawancara dengan Ketua AWAYO. 
perang harga. Sebagai contoh, tarif warnet di kota Yogyakarta berkisar Rp 3.000,00 - Rp. $4.000,00$. Beberapa pemodal besar juga memasuki bisnis industri warnet, hal ini oleh beberapa pengamat dianggap sebagai salah satu faktor penyebab tergusurnya bisnis warnet skala kecil (Mas'udi, 2001).

Kinerja koneksi menjadi faktor yang strategis dan penting dalam persaingan dalam industri internet. Warnet yang tidak menyediakan akses koneksi internet yang cepat dan lancar, dapat dipastikan cepat atau lambat akan tersisih atau kalah bersaing. Kondisi tersebut bukannya tidak disadari oleh pemilik atau pengelola warnet di Yogyakarta. Hal ini dapat dilihat dari adanya perubahan teknologi koneksi yang digunakan, yaitu dari teknologi koneksi dial-up menjadi teknologi wireless.

Berdasarkan latar belakang tersebut maka masalah yang diajukan dalam riset ini ini adalah bagaimanakah kinerja koneksi internet warnet di Yogyakarta? Kinerja koneksi akan dilihat dari kecepatan dan kualitas koneksi serta layanan koneksi yang diberikan oleh ISP (internet service provider) terhadap warnet. Di samping itu juga akan dilihat rencana dan kemampuan investasi pemilik atau pengusaha warnet untuk meningkatkan kinerja koneksi internet.

\section{METODA PENELITIAN}

Data yang digunakan untuk analisis, terdiri dari: (1) data primer, dan (2) data sekunder. Data primer diperoleh dengan survei lapangan, dan pemilihan sampel sebagai responden dalam riset berdasarkan kesediaan pemilik/pengelola warnet untuk dijadikan responden. Untuk memperoleh data dan informasi dari responden dilakukan wawancara berdasarkan kuesioner yang telah disiapkan. Sedangkan untuk memperoleh informasi yang lebih rinci dan mendalam, maka dilakukan wawancara mendalam terhadap 10 responden yang menjadi sampel dalam riset ini. Tujuan wawancara tersebut untuk menggali informasi yang lebih mendalam dari responden.

Kemudian data sekunder diperoleh dari sumber-sumber publikasi sekunder (majalah/koran, jurnal, laporan hasil penelitian, dan internet). Sedangkan analisis dilakukan secara deskriptif didasarkan pada data dan informasi yang diperoleh. Data dan informasi yang diperoleh setelah diolah kemudian dianalisis secara kualitatif berdasarkan statistik deskriptif.

\section{DESKRIPSI HASIL SURVEY}

Survei yang dilakukan memperoleh sampel sebanyak 159 warnet. Dari jumlah tersebut sebanyak 12 pemilik/pengelola warnet menolak untuk dijadikan responden. Responden merupakan pemilik atau pengelola warnet. Selanjutnya sebanyak 7 buah kuesioner tidak layak untuk dianalisis lebih lanjut, sehingga jumlah kuesioner yang dianalisis sebanyak 140 buah. Pengisian kuesioner dilakukan dengan metode wawancara terpandu (quided interview). Survei dilakukan pada minggu pertama bulan Maret 2002.

Untuk mempertajam hasil survei dan cek silang hasil survei, dilakukan wawancara mendalam (indepth interview) terhadap 10 responden terpilih. Dengan wawancara mendalam tersebut diharapkan informasi yang lebih mendalam dan lebih luas dibandingkan informasi yang digali dari daftar pertanyaan sebelumnya. Dari hasil survei ini diharapkan memperoleh gambaran atau profil mengenai kinerja koneksi warnet di Yogyakarta terutama dari sisi: (1) jenis dan kemampuan koneksi jaringan dari ISP, (2) rencana untuk meningkatkan kemampuan koneksi, (3) kualitas layanan koneksi, (4) dan hal-hal lain yang berkaitan dengan kinerja koneksi.

Lokasi warnet di Yogyakarta pada umumnya terkonsentrasi di lingkungan kampus, khususnya beberapa kampus di Yogyakarta Utara dan Yogyakarta Timur. Setidaknya ada 4 wilayah dimana lokasi warnet terkonsentrasi. Wilayah pertama di seputar kampus UGM (Universitas Gadjah Mada) Bulaksumur, tepatnya di seputar Jl. Kaliurang dari Km 6 sampai dengan Km 8. Sedangkan wilayah Jl. Kolombo, dan Jl. Gejayan - Mrican juga terdapat banyak warnet, karena di wilayah tersebut setidaknya terdapat kampus UNY (Universitas Negeri Yogyakarta), USD (Universitas Sanata Dharma), dan UAJY (Universitas Atma Jaya Yogyakarta) 
Kampus Mrican. Lokasi warnet lainnya di seputar Babarsari dan Seturan, Yogyakarta Timur, di wilayah tersebut terdapat kampus UAJY Babarsari, STIE YKPN dan UPN Veteran.

Wilayah selanjutnya adalah Condongcatur dan sekitarnya. Di samping terdapat kampus UII (Universitas Islam Indonesia), STIE Nusa Megarkencana, STIMIK Akakom, dan USD Kampus Paingan, daerah tersebut tersebut juga dipadati oleh pondokan mahasiswa. Tidak heran jika di wilayah tersbut juga cukup banyak terdapat warnet. Lokasi warnet lainnya tersebar di wilayah Yogyakarta Tengah dan Yogyakarta Selatan, namun jumlahnya relatif sedikit. Dari pemetaan lokasi, maka lokasi warnet pada umumnya di wilayah di sekitar kampus dan pondokan mahasiswa.

Industri warnet di Yogyakarta berkembang dengan pesat mulai tahun 1999. Ada sebanyak 20 warnet ( $14,26 \%)$, yang mulai beroperasi pada tahun 1999. Warnet yang mulai beroperasi pada tahun 2000 dan 2001, masing-masing sebanyak 48 warnet $(34,26 \%)$ dan 59 warnet $(42,14 \%)$. Untuk warnet yang beroperasi sebelum tahun 1999 jumlah relatif sedikit, di samping itu ada beberapa warnet yang berdiri pada awal tahun 2002.

Dari jumlah warnet yang ada mereka umumnya beroperasi dengan jumlah PC (Personal Computer) sampai dengan 20 unit adalah sebanyak 114 warnet (81,43\%). Selanjutnya ada 22 $(15,71 \%)$ warnet yang mengoperasikan PC sebanyak 21 - 40 buah. Dengan kondisi tersebut, sebagian besar dari mereka (69,29\%) menyatakan tidak akan menambah jumlah PC yang digunakan untuk warnetnya. Sedangkan sisanya sebanyak 30,71\% menyatakan akan menambah jumlah PC-nya.

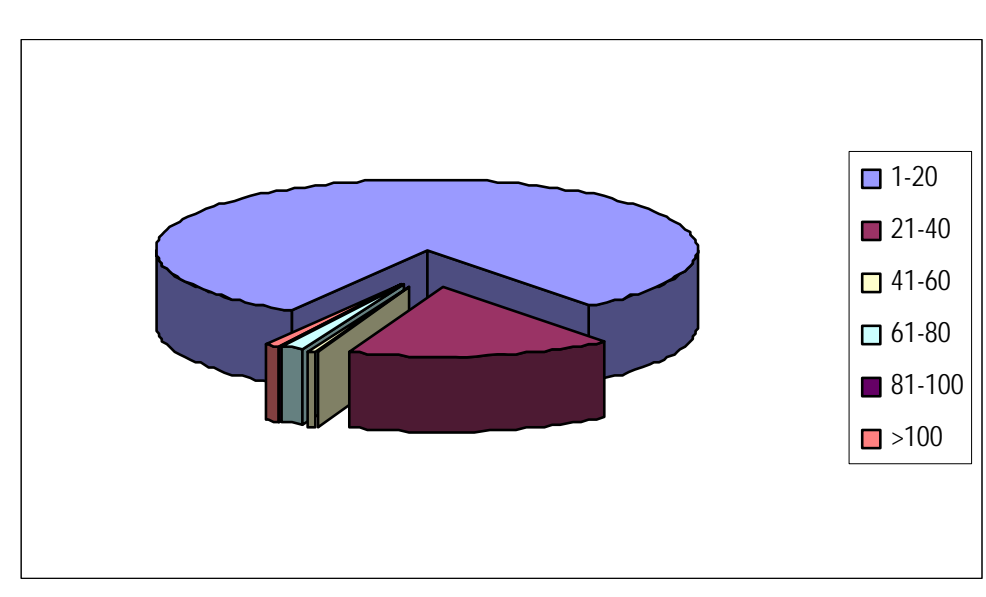

Gambar 1. Jumlah PC

Dari responden yang menyatakan keinginan menambah jumlah PC-nya tersebut, maka sebanyak 16 pemilik/pengelola warnet $(37,21 \%)$ akan merealisasikan rencana tersebut dalam satu tahun. Sebanyak 8 pemilik/pengelola warnet menyatakan akan menambah PC-nya dalam kurun setahun mendatang. Selanjutnya yang menyatakan ingin menambah PC-nya dalam jangka waktu 3 bulan dan 1 bulan mendatang masing-masing sebanyak 6 pemilik/pengelola warnet (13,95\%). Dari mereka yang merencanakan menambah PC, maka sebagian besar akan menambah dalam jumlah 1 - 10 unit $(93,01 \%)$. Dengan demikian rencana penambahan PC yang akan dilakukan memang dalam jumlah yang terbatas. 


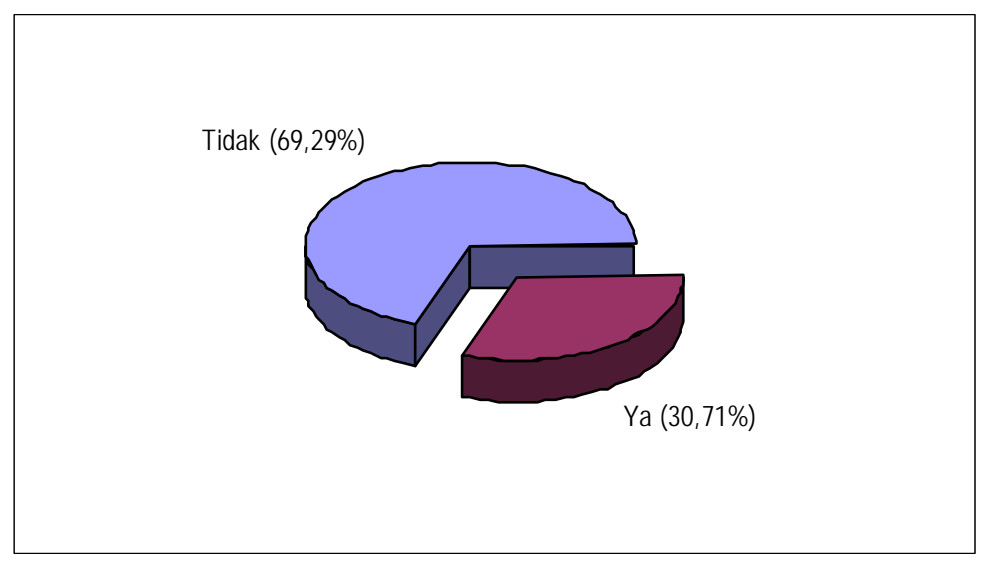

Gambar 2. Keinginan Menambah Jumlah PC

Persaingan antar warnet di Yogyakarta cukup ketat (lihat juga Anonim, 2001). Hal ini dilihat dari persaingan harga yang terjadi, dan jumlah warnet dalam satu lokasi yang berdekatan. Dari sisi harga, pada jam-jam tertentu mereka memberikan tarif khusus. Tarif warnet di Yogyakarta pada saat survei dilakukan berkisar Rp 2.000,00 sampai dengan Rp 3.000,00 per jam. Dari hasil survei ternyata pada radius 500 meter terdapat warnet lebih dari satu buah. Responden yang menyatakan dalam radius tersebut terdapat 2 warnet lainnya $(18,57 \%)$, 3 warnet $(18,57 \%), 4$ warnet (15,00\%), 5 warnet $(17,14 \%)$, dan 6 warnet lainnya (6,43\%). Berdekatannya lokasi antara warnet dapat ditemui di wilayah JI. Kaliurang, Seturan, Condongcatur, dan Gejayan-Mrican.

\subsection{Kinerja Koneksi}

Dari 140 responden yang ada sebagian besar menggunakan fasilitas jaringan ISP (Internet Service Provider) PSN yaitu sebanyak 40 warnet $(28,57 \%)$. Perusahaan jasa ISP yang dipilih oleh pemilik/pengelola warnet di Yogyakarta masing-masing adalah Indosat (13,57\%), Link Net $(10,00 \%)$, Jalawave $(7,85 \%)$, Sat Net $(5,71 \%)$, Commsat $(5,00 \%)$ dan siasanya tersebar pada beberapa ISP. Pilihan ISP di Yogyakarta memang cukup banyak, dari hasil survei setidaknya ada 24 perusahaan jasa ISP yang menjadi pemasok industri warnet di Yogyakarta.

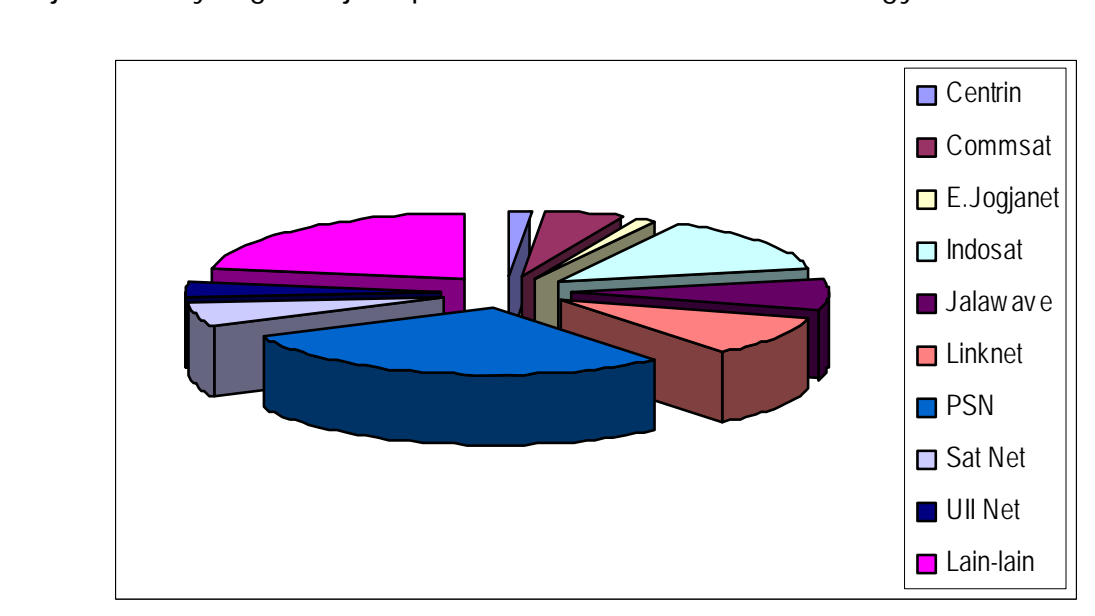

Gambar 3. Internet Service Provider yang Digunakan

Selanjutnya jenis koneksi yang ada pada warnet tersebut sebagian besar menggunakan Wireless 2,4 GHz yaitu sebanyak 76 buah (54,29\%), kemudian masing-masing diikuti dengan jenis koneksi satelit (14,26\%), LC (12,14\%), Wireless $5,8 \mathrm{GHz}$ (7,58\%), dial-up (5,21\%), dan yang 
menggunakan jenis koneksi lainnya relatif sangat sedikit. Sedangkan kecepatan koneksi yang ada mayoritas pada kecepatan 64 kbps (51,43\%), kemudian diikuti dengan kecepatan 128 kbps (24,29\%), $256 \mathrm{kbps}(5,71 \%), 512 \mathrm{kbps}(4,29 \%)$, dan 56 kbps (4,29\%). Ada sebanyak 14 warnet $(14,00 \%)$ yang mengaku mempunyai kecepatan koneksi di luar kecepatan di atas.

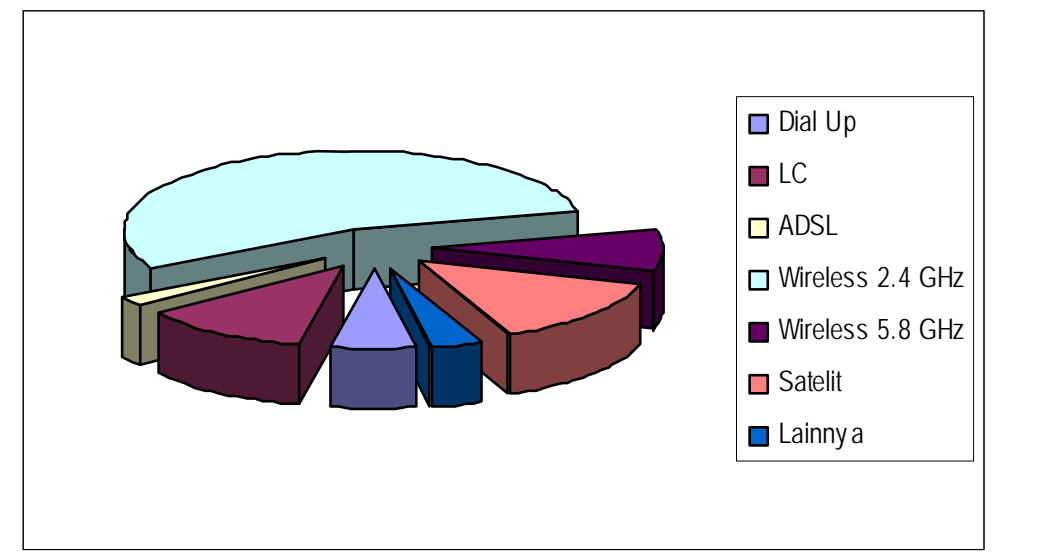

Gambar 4. Internet Service Provider yang Digunakan

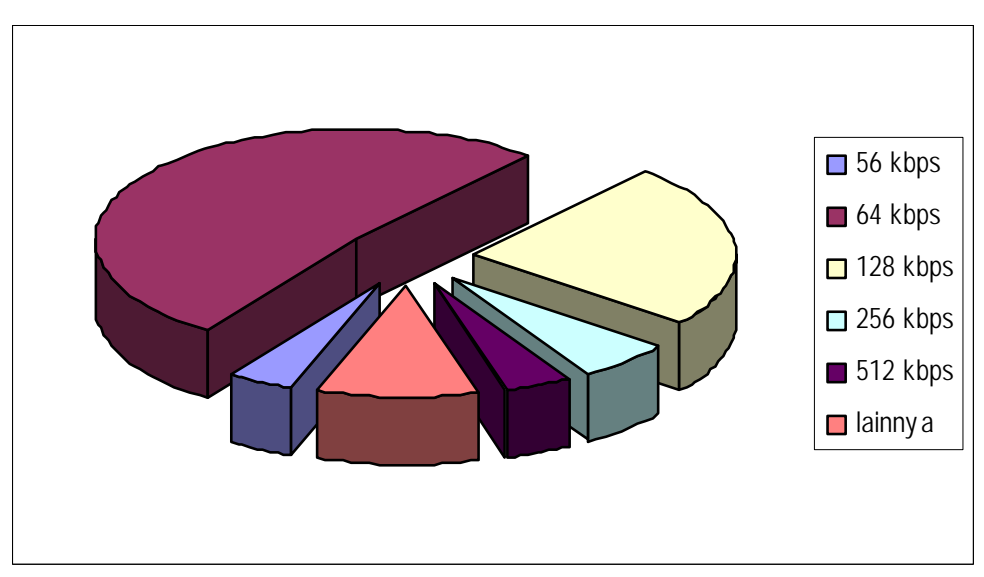

Gambar 5. Kecepatan Koneksi

Berkaitan dengan kecepatan koneksi yang ada sebagian besar yaitu 99 pemilik/pengelola warnet $(70,71 \%)$ menyatakan bahwa kecepatan yang sudah mencukupi atau memadai. Sekitar $30 \%$ reponden lainnya menyatakan kecepatan koneksi kurang dan yang menyakatkan sangat kurang sebanyak 2 responden (1,14\%). Sedangkan responden yang menyatakan kecepatan koneksi lebih dari cukup hanya sebanyak 6,38\%. 


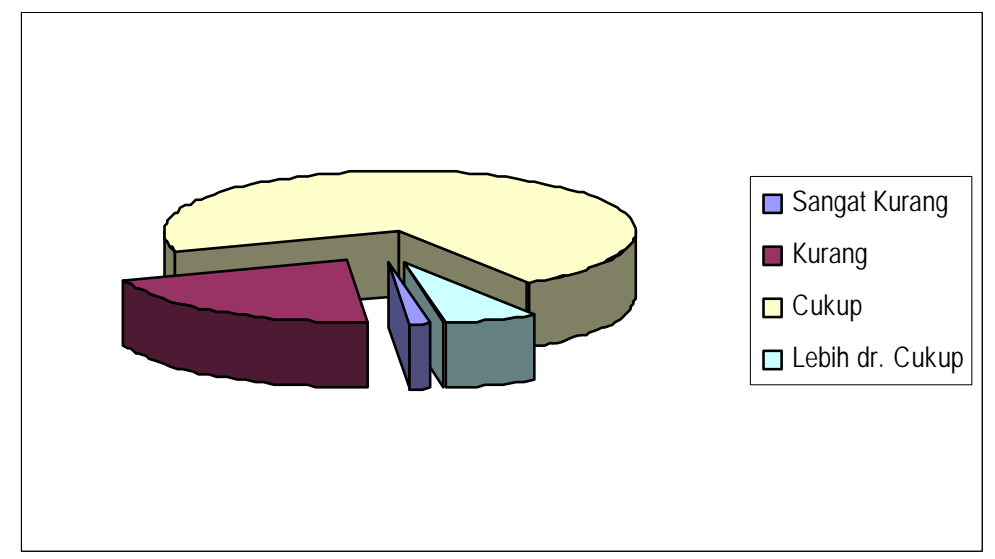

Gambar 6. Kecepatan Koneksi

Bagaimanakah penilaian responden terhadap kualitas koneksi internet yang disediakan oleh perusahaan-perusahaan jasa ISP? Jumlah responden yang menyatakan kualitas koneksi baik sebanyak 40 responden $(28,57 \%)$ dan yang menyatakan cukup sebanyak 60 responden $(42,86 \%)$. Sedangkan yang menyatakan kurang sebanyak 23,57\% dan jelek sebanyak 2,14\%. Responden yang menyatakan bahwa kualitas koneksi sangat baik hanya sebanyak $2,84 \%$ saja.

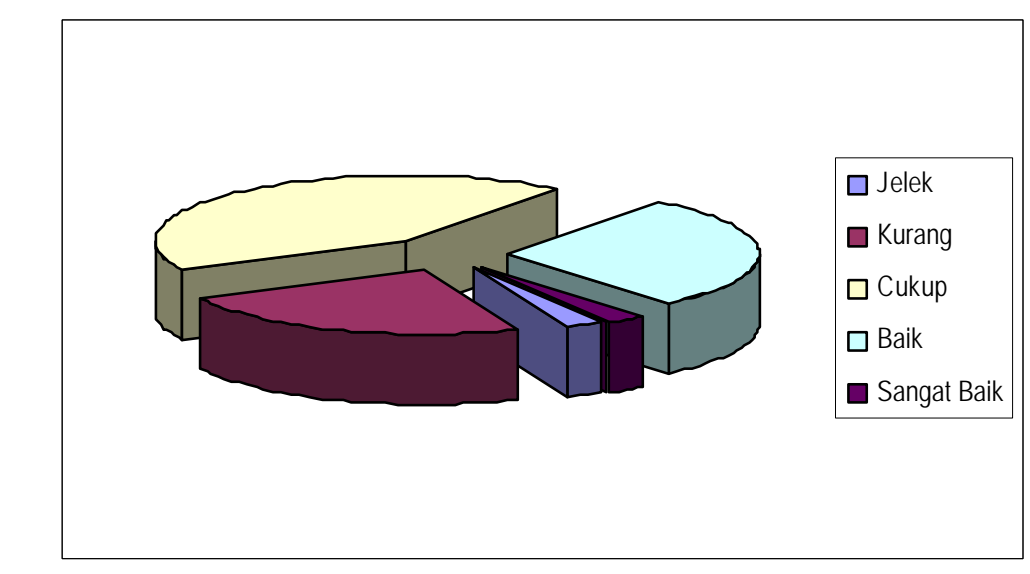

Gambar 7. Penilaian terhadap ISP

Selanjutnya sebanyak 125 responden $(89,29 \%)$ menyatakan koneksi pada jaringan warnetnya pernah terputus dan hanya 15 responden $(10,71 \%)$ yang menyatakan koneksinya tidak pernah putus. Berkaitan dengan putusnya koneksi, maka sebanyak 15 responden $(10,71 \%)$ menyatakan putusnya setiap hari, setiap minggu $(25,71 \%)$, setiap bulan $(35,71 \%)$ dan lainnya sebanyak $15,00 \%$. 


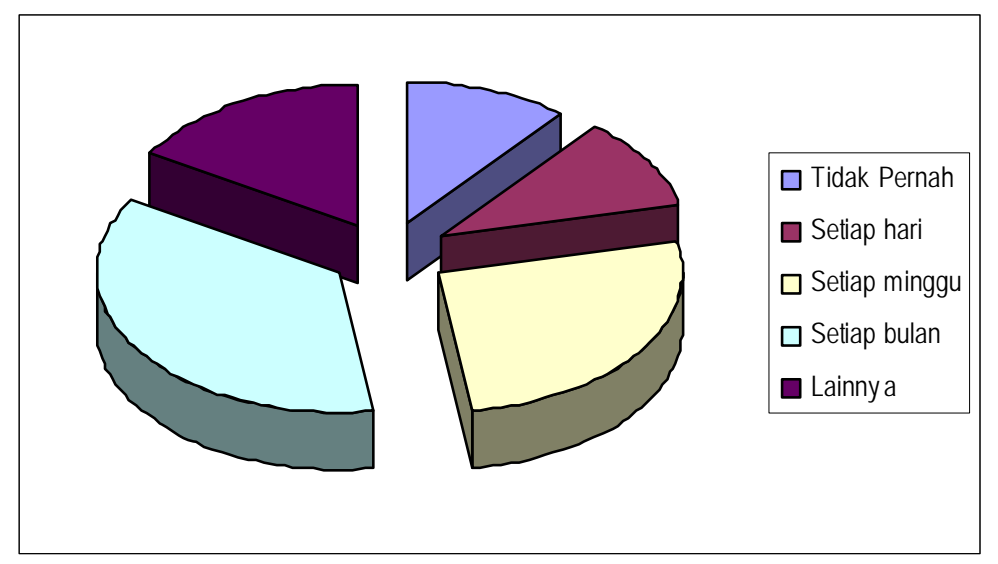

Gambar 8. Seberapa sering Koneksi Terputus

Besarnya biaya pendaftaran untuk memperoleh koneksi dari ISP sangat bervariasi. Sebanyak 58 responden (41,43\%) yang menyatakan membayar antara Rp 100.000,00 - Rp 1.000.000,00. Yang membayar biaya pendaftaran sebesar Rp 1.100.000,00 - Rp. 2.000.000,00 sebanyak 40 responden (28,57\%). Sedangkan yang membayar Rp 2.000.100,00 - Rp Rp $5.000 .000,00$ sebanyak 22 responden $(15,71 \%)$. Selanjutnya 20 responden $(14,29 \%)$ menyatakan membayar biaya pendaftaran sebesar Rp 5.000.100,00 - Rp 25.000.000,00.

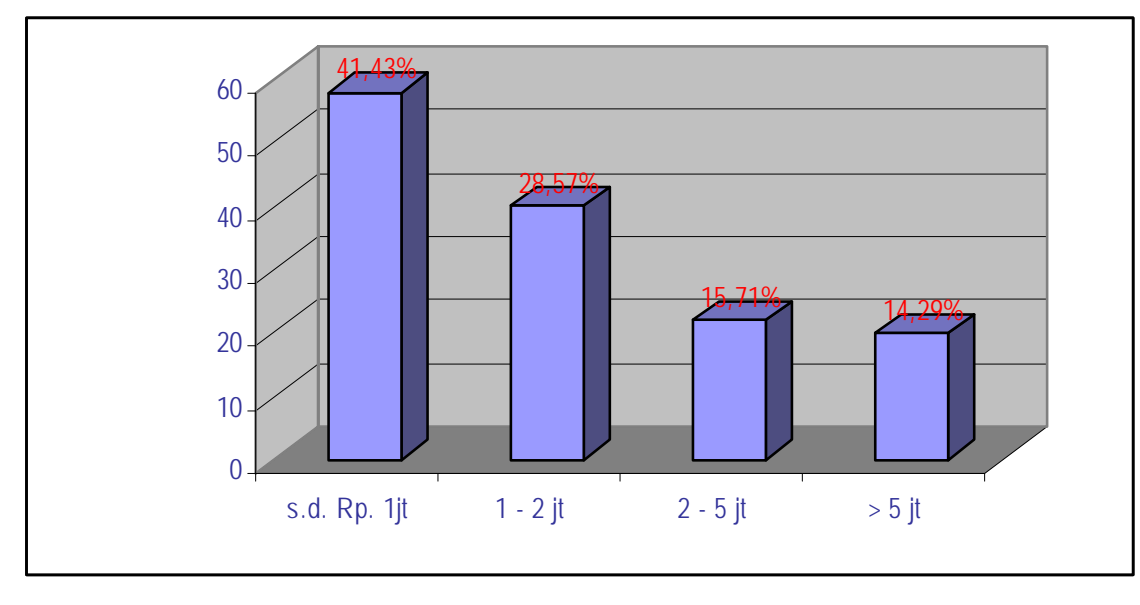

Gambar 9. Biaya Pendafataran ISP

Biaya bulanan yang harus dibayarkan kepada pihak ISP oleh warnet di Yogyakarta juga sangat bervariasi. Dari hasil survai, 15 responden $(10,71 \%)$ menyatakan mengeluarkan biaya Rp 1.000.000,00 - Rp 2.500.000,00. Selanjutnya yang membayar antara Rp Rp 2.500.100,00 - Rp $5.000 .000,00$ sebanyak 78 responden (55,71\%). Untuk biaya sebesar Rp 5.000.100,00 - Rp $7.500 .000,00$ dibayar oleh 17 responden (12,14\%). Sedangkan biaya sebesar Rp 7.500.100,00 Rp 10.000.000,00 dibayar oleh 18 responden (12,86\%) dan sisanya sebanyak 8,57\% responden membayar Rp 10.000.100,00 - Rp 15.000.000,00. 


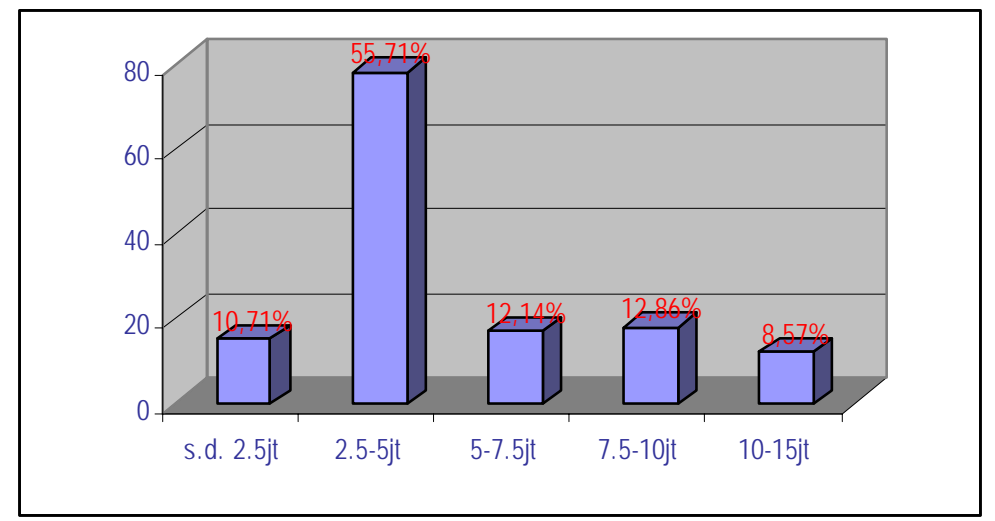

Gambar 10. Biaya Bulanan ISP

Dengan membayar bulanan tersebut di samping memperoleh fasilitas koneksi juga memperoleh fasilitas: (1) free web hosting, (2) static IP, (3) alamat email, (4) fasilitas lainnya. Sebagian responden memperoleh fasilitas static IP $(63,57 \%)$, email $(25,71 \%)$, free web hosting $(7,86 \%)$, dan fasilitas lainnya $(3,26 \%)$. Jumlah fasilitas yang diterima masing-masing warnet berbeda-beda tergantung dari perusahaan ISP-nya.

\subsection{Rencana Investasi}

Dari 140 reponden dalam survei ini, sebanyak 91 responden (65,00\%) menyatakan ingin meningkatkan kecepatan koneksi yang ada pada warnetnya. Kecepatan koneksi yang diinginkan berbeda-beda tergantung dari infrastruktur dan kemampuan finansial dari pemilik warnet. Sebanyak 49 responden $(53,85 \%)$ menginginkan kecepatan koneksi menjadi 128 kbps, 256 kbps $(23,08 \%), 64 \mathrm{kbps}(9,89 \%), 512 \mathrm{kbps}(7,69 \%)$, dan lainnya sebanyak 5 responden $(5,49 \%)$.

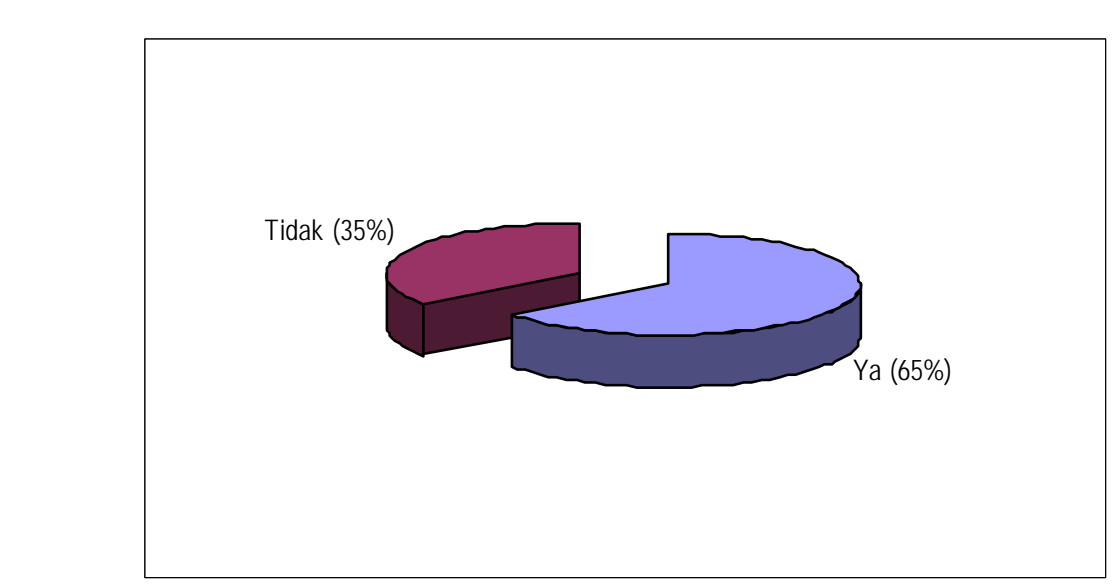

Gambar 11. Rencana Investasi 


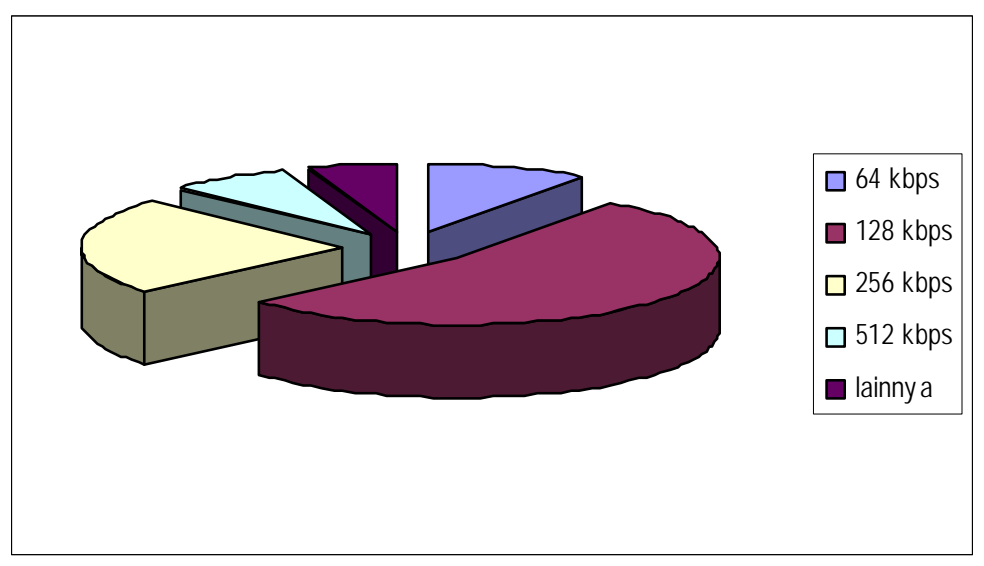

Gambar 12. Kecepatan yang diinginkan

Berkaitan dengan keinginan untuk meningkatkan kecepatan koneksi, maka responden menginginkan jenis koneksi tertentu. Jenis koneksi termaksud adalah LC (15,38\%), TV Cable (14,29\%), ADSL (7,77\%), Wireless $2,4 \mathrm{GHz}(30,77 \%)$, Wireless $5,8 \mathrm{GHz}(10,99 \%)$, dan sebanyak 30 responden $(32,97 \%)$ menginginkan jenis koneksi dengan menggunakan satelit. Berkaitan dengan kemauan untuk membayar (willingness to pay) dari responden atas fasilitas yang mereka inginkan, pada umumnya mereka tidak menjawab dengan pasti. Pada dasarnya mereka sudah mengetahui tarif yang berlaku pada saat ini dan akan melakukan studi kelayakan (feasibility study) sebelum melakukan tambahan investasi untuk meningkatkan kemampuan koneksi pada warnetnya.

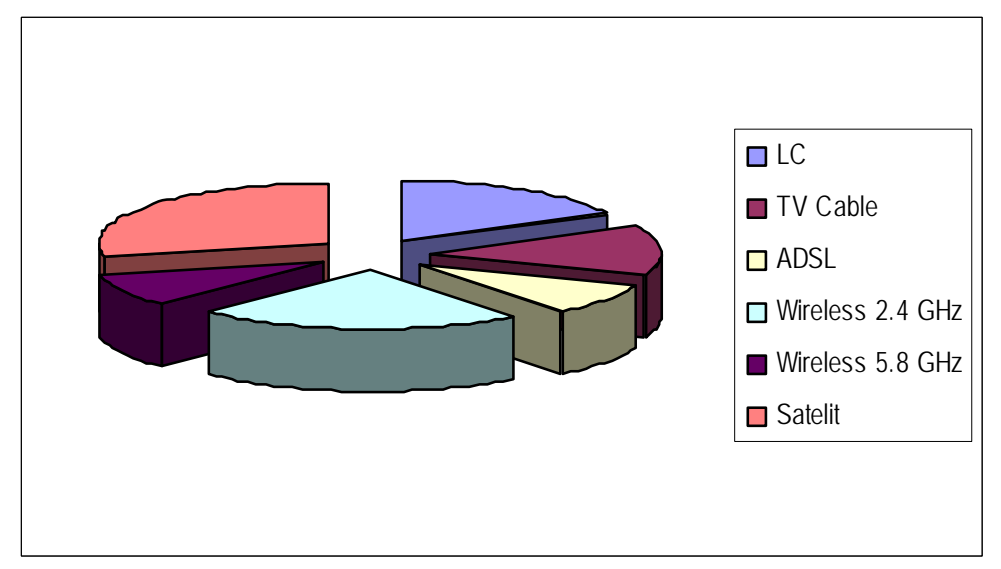

Gambar 13. Jenis Koneksi yang diinginkan

Pada umumnya jawaban yang sama muncul atas pertanyaan besarnya investasi awal (CPE dan instalasi) untuk meningkatkan kinerja koneksi yang akan mereka keluarkan. Namun jika responden "dipaksa" untuk menjawab maka terdapat beberapa variasi jawaban. Responden yang bersedia melakukan investasi awal sebesar Rp 1.000.000,00 - Rp 5.000.000,00 sebanyak 23 orang (25,27\%). Sedangkan yang bersedia melakukan investasi awal sebesar Rp 5.000.100,00 Rp 10.000.000,00 sebanyak 18 responden (19,78\%), Rp 10.000.100,00 - Rp 20.000.000,00 sebanyak 9 responden $(9,89 \%)$, dan sebanyak 14 responden $(15,38 \%)$ yang menyatakan bersedia melakukan investasi awal Rp 20.000.100,00 - Rp 50.000.000,00. Selanjutnya yang bersedia mengeluarkan investasi awal Rp 50.000.100,00 - Rp 100.000.000,00 sebanyak 11 responden (12,09\%). Untuk investasi awal sejumlah Rp 100.000.100,00 - Rp 200.000.000,00 juga sebanyak 
11 responden (12,09\%), sedangkan untuk jumlah Rp 200.000.100,00 - Rp 400.000.000,00 dinyatakan oleh 5 responden $(5,49 \%)$.

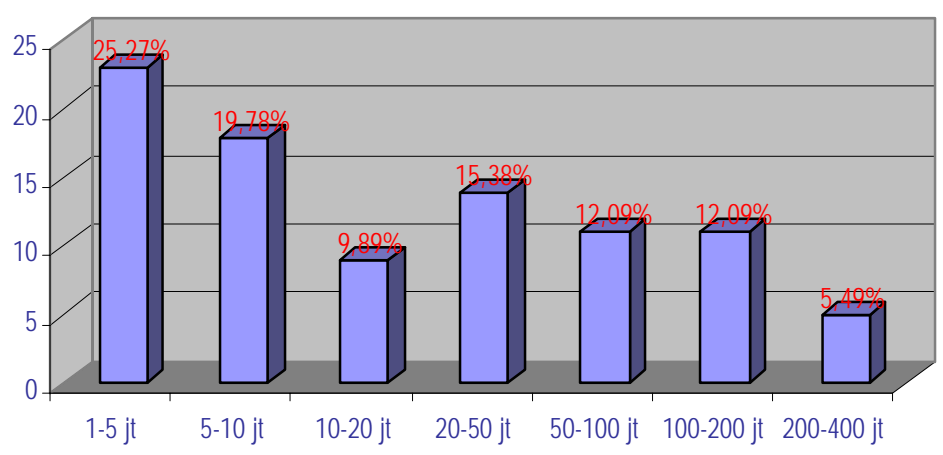

Gambar 14. Besarnya Investasi Awal

Dari responden yang bersedia investasi untuk meningkatkan koneksi maka sebanyak 48 orang $(63,74 \%)$ dilakukan dengan cara membeli, 25 responden $(27,47 \%)$ dengan cara sewa, dan sisanya sebanyak 8 responden $(8,79 \%)$ dalam bentuk lainnya. Dari hasil wawancara mendalam dengan beberapa pemilik dan pengelola warnet, untuk investasi awal dalam kaitan untuk meningkatkan kinerja koneksi dalam nilai di atas Rp 100.000.000,00 sangat berat dan mereka bertanya apakah feasibel. Mereka juga menyatakan hal tersebut bisa saja jika didukung oleh pemodal yang kuat dan biasanya dari luar Yogyakarta.

Berkaitan dengan memilih akses internet, para pemilik atau pengelola internet pada umumnya berpendapatan bahwa: (1) kualitas koneksi, (2) harga investasi peralatan, (3) harga bulanan, (4) bandwith, (5) fasilitas selain akses, dan (6) layanan customer service sebagain besar responden pada umumnya menyatakan sangat penting. Dalam hal variabel kualitas koneksi sebanyak 123 responden $(87,23 \%)$ menyatakan sangat penting, yang berpendapatan lain relatif sedikit jumlahnya. Untuk faktor atau variabel harga investasi peralatan $44,29 \%$ responden menyatakan sangat penting, penting (25,00\%), sedang $(22,14 \%)$, tidak penting $(5,71 \%)$, dan sangat tidak penting $(2,14 \%)$. Sedangkan harga bulanan dianggap menjadi faktor yang sangat penting oleh 86 responden $(61,43 \%)$, penting $(22,86 \%)$, sedang $(10,00 \%)$, tidak penting $(2,86 \%)$, dan yang menyatakan sangat tidak penting sebanyak 4 responden $(2,86 \%)$. Dari sisi faktor bandwith sebanyak 98 responden $(70,00 \%)$ menyatakan hal yang sangat penting untuk memilih akses internet. Selanjutnya sebanyak 24 responden $(17,14 \%)$ menyatakan penting, sedang $(9,29 \%)$, tidak penting $(2,14 \%)$, dan 2 responden menyatakan sangat tidak penting. 
KINERJA, Volume 8, No. 1, Th. 2004: Hal. 56-69

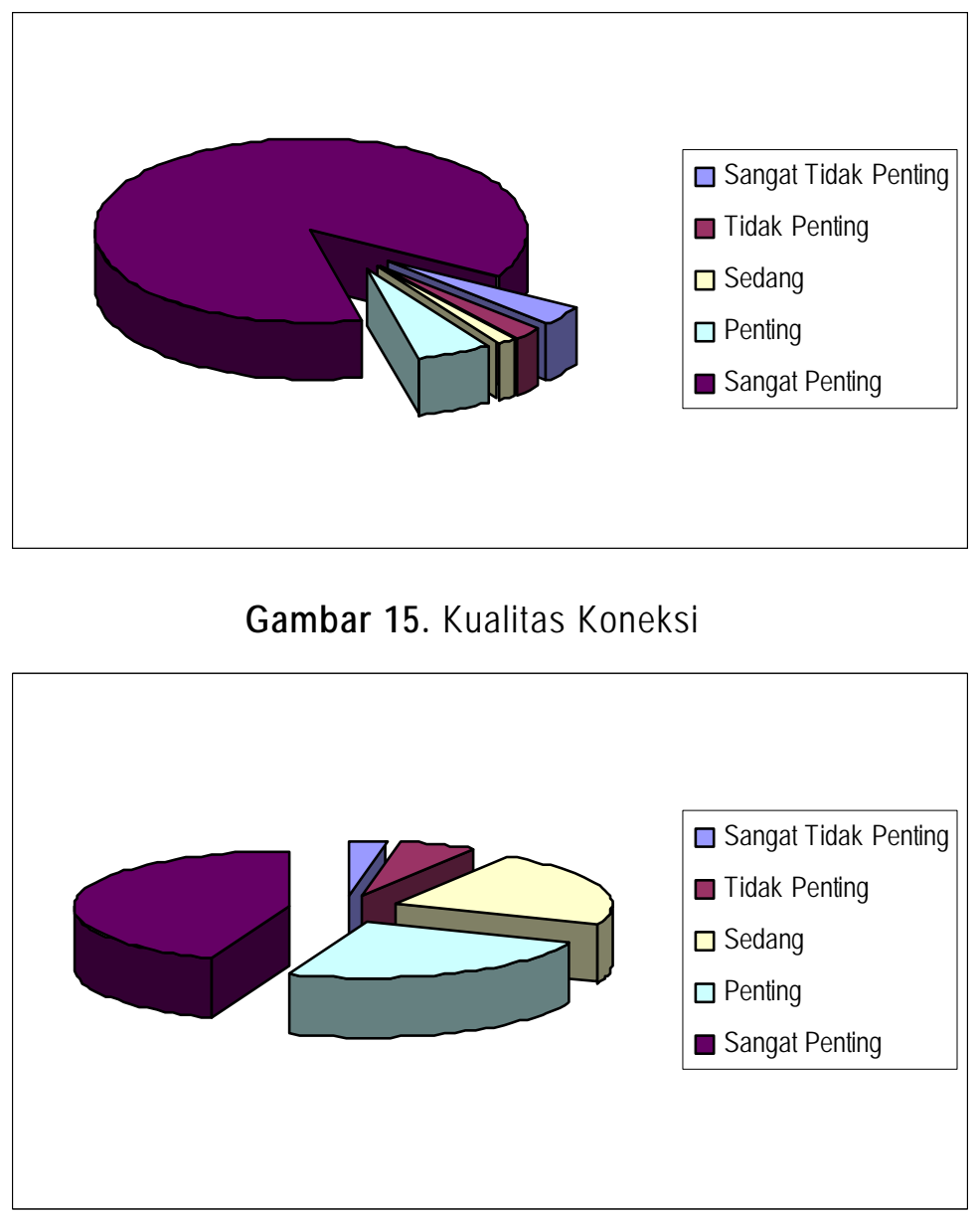

Gambar 16. Harga Investasi Peralatan

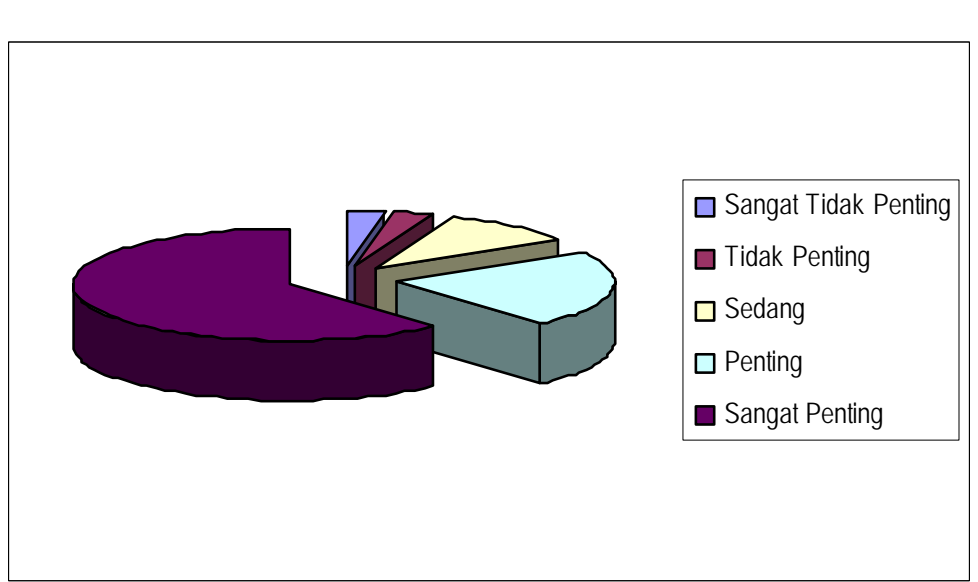

Gambar 17. Harga Bulanan (langganan)

Sebanyak 55 responden $(29,29 \%)$ menyatakan bahwa variabel fasilitas selain akses sangat penting. Responden lainnya sebanyak $24,64 \%$ menyatakan penting, sedang $(27,14 \%)$, tidak penting $(5,07 \%)$, dan sisanya menyatakan sangat tidak penting. Mengenai layanan kepada 
pelanggan $74,29 \%$ atau 104 responden menyatakan sangat penting. Selanjutnya sebanyak 22 responden $(15,71 \%)$ menyatakan penting, sedang $(4,32 \%)$, tidak penting $(2,86 \%)$, dan sebanyak 4 responden $(2,88 \%)$ menyatakan sangat tidak penting. Berkaitan dengan pilihan koneksi yang tersedia untuk Warnet di Yogyakarta adalah: (1) LC, (2) TV cable, (3) ADSL, (4) Wireless 2,4 GHz, (5) Wireless $5,8 \mathrm{GHz}$, dan (6) Satelit. Dengan demikian teknologi koneksi untuk warnet di Yogyakarta sudah tersedia berbagai alternatif dengan masing-masing keterbatasan dan keunggulannya.

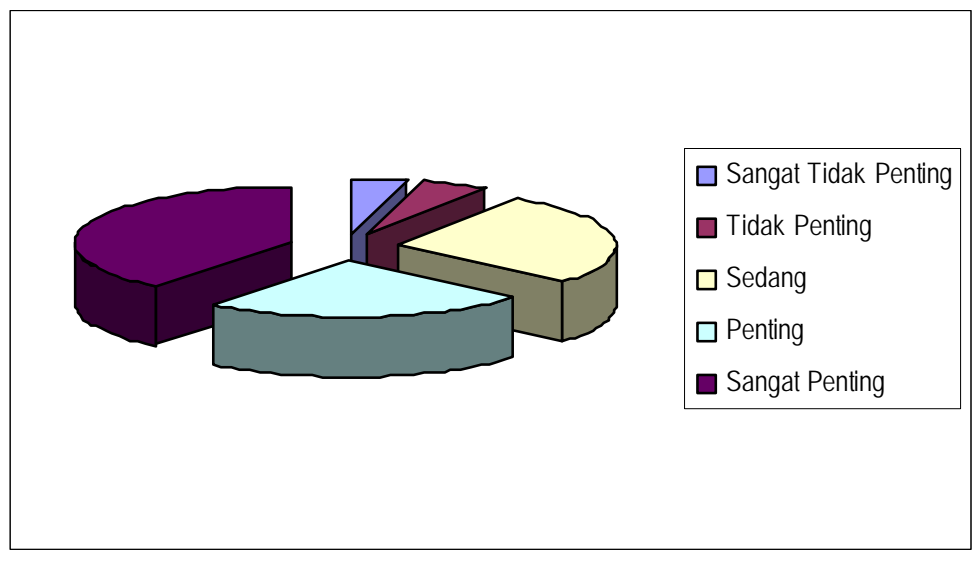

Gambar 18. Variabel Selain Akses

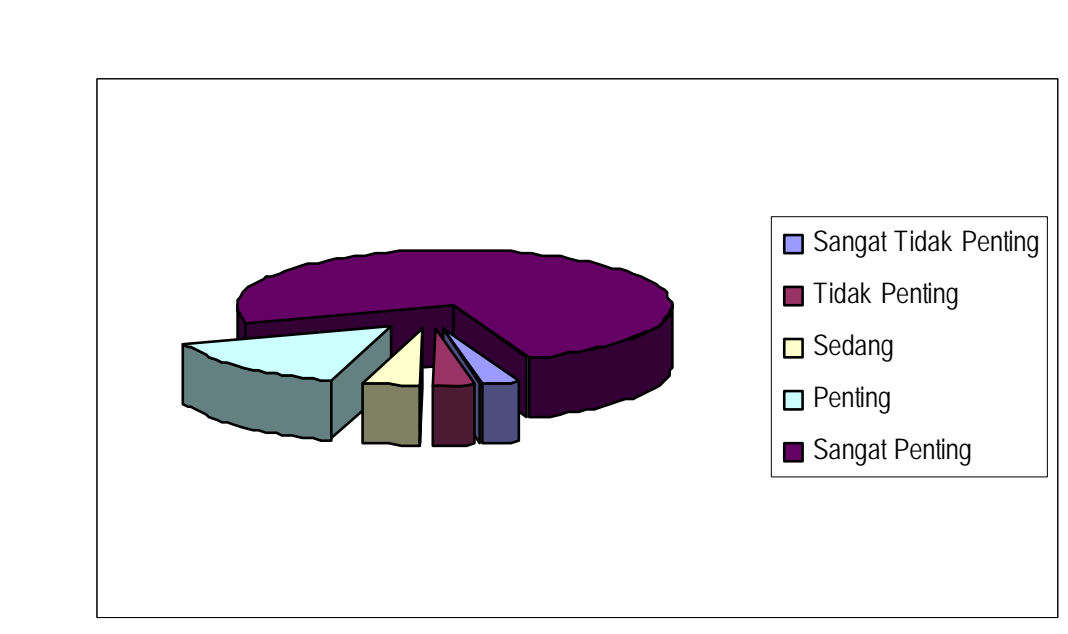

Gambar 19. Layanan Kepada Pelanggan

\section{PENUTUP}

Meskipun persaingan cukup ketat, namun beberapa pemilik atau pengelola menyatakan bahwa prospek industri warnet di Yogyakarta masih cukup cerah. Mereka akan menggali potensi pasar yang lebih dalam, khususnya dari kalangan pelajar dan mahasiswa. Yogyakarta di kenal dengan kota pelajar, menurut pemilik atau pengelola warnet banyak mahasiswa belum menggunakan fasilitas internet warnet. Kecenderungan internet sebagai salah satu sumber untuk mencari referensi untuk tugas semakin meningkat, internet tidak hanya sebagai sumber informasi ringan dan hiburan tetapi juga sumber informasi akademik. Salah hal itulah yang menyebabkan pemilik atau pengelola internet optimis akan prospek bisnis internet di Yogyakarta.

Secara nasional jumlah pengguna internet pada tahun 2002 diperkirakan sekitar 4,2 juta orang (Indocommercial, 2002; Hendaru, 2002). Jumlah tersebut merupakan Ionjakan yang 
signfikan dibandingkan jumlah penggunan internet pada tahun 1998 yang hanya sebanyak 421.000 orang. Di Yogyakarta terdapat sekitar 80 perguruan tinggi, dan jumlah mahasiswanya tidak kurang dari 200.000 orang. Dengan asumsi $10 \%{ }^{3}$ dari jumlah mahasiswa yang ada sebagai pengguna internet yang aktif, maka setidaknya terdapat 20.000 mahasiswa yang menjadi pasar yang potensial bagi industri warnet di Yogyakarta. Pasar potensial tersebut belum memperhitungkan jumlah pelajar, khususnya SLTA, yang jumlah diperkirakan puluhan ribu.

Dari hasil riset atau penelitian survei maka diperoleh kesimpulan sebagai berikut: (1) Sebagian besar warnet di Yogyakarta (81,43\%) merupakan warnet skala kecil dengan jumlah PC sebanyak 1 - 20 buah. Dari jumlah tersebut, sebagian besar dari mereka (64,29\%) tidak akan menambah jumlah PC untuk warnet. Sedangkan yang ingin menambah jumlah PC, tambahannya sebagain besar dalam jumlah 1 - 10 unit.

Selanjutnya mayoritas warnet di Yogyakarta menggunakan jenis koneksi wireless $2,4 \mathrm{GHz}$ $(54,29 \%)$ dan kecepatan koneksi 64 kbps $(51,43 \%)$. Berkaitan dengan kinerja koneksi responden menyatakan kecepatan koneksi yang ada dianggap sudah cukup memenuhi kebutuhan $(70,71 \%)$ dan kualitas koneksi dianggap juga cukup (42,86\%). Kondisi ini tentu sangat berkaitan dengan kondisi industri warnet yang mayoritas merupakan skala kecil.

Kemudian sebanyak 91 responden menginginkan peningkatan kinerja koneksi (65,00\%). Sedangkan kecepatan koneksi yang diinginkan oleh mereka adalah 128 kbps (49 responden atau $53,85 \%$ ) dan 256 kbps (21 responden atau 23,08\%). Jenis koneksi yang dipilih adalah satelit (32,97\%), wireless $2,4 \mathrm{GHz}(30,77 \%)$, LC (15,38\%), TV Cable (12,62\%), Wireless $5,8 \mathrm{GHz}$ (10,99\%), dan ADSL $(8,79 \%)$.

Berkaitan untuk meningkatkan kinerja koneksi sebanyak 23 responden $(25,27 \%)$ menyatakan akan menyediakan investasi awal Rp 1.000.000,00 - Rp 5.000.000,00, 18 responden $(19,78 \%)$ menyatakan akan mengeluarkan investasi awal sebesar Rp Rp 5.000.100,00 - Rp 10.000.000,00. Selanjutnya jumlah investasi awal sebesar Rp 10.000.100,00 - Rp 20.000.000,00 akan dikeluarkan oleh 9 responden $(9,89 \%)$, dan 14 responden $(15,38 \%)$ menyatakan kesediaan untuk mengeluarkan investasi awal sebanyak Rp 20.000.100,00 - Rp 50.000.000,00. Untuk investasi awal sebesar Rp 50.000.100,00 - Rp 100.000.000,00 akan dikeluarkan oleh 11 responden $(12,09 \%)$ dan sebanyak 11 responden juga akan mengeluarkan dana sebesar Rp 100.000.100,00 - Rp 200.000.000,00. Untuk investasi awal paling besar yaitu Rp 200.000.100,00 - Rp 400.000.000,00 akan dikeluarkan oleh 5 responden (3,28\%).

Yang terakhir responden berpendapatan bahwa: (1) kualitas koneksi, (2) harga investasi peralatan, (3) harga bulanan, (4) bandwith, (5) fasilitas selain akses, dan (6) layanan terhadap pelanggan (customer service) merupakan variabel atau faktor yang sangat penting sebagai dasar pengambilan keputusan untuk memilih akses internet.

\section{DAFTAR PUSTAKA}

Anonim (2002), "Statistik Laporan Dewan Pengurus APJII", diakses dari www.apjii.or.id pada tanggal 15 September 2002.

Anonim, (2001), "Komputer: Ketatnya Kompetisi Warnet, Siapa Bertahan?", Kedaulatan Rakyat, 24 September 2001, diakses dari www.kr.co.id tanggal 5 Maret 2002.

Hendaru, (2002), "Pengguna Internet Indonesia Capai 4,2 Juta", Warta Ekonomi, 11Januari 2002, diakses dari www.wartaekonomi.com tanggal 5 Maret 2002.

\footnotetext{
${ }^{3}$ Perkiraan penulis dengan ketua AWAYO.
} 
Indocommercial, (2002), "Pengguna Internet 2002 Diperkirakan Meningkat", CIC Indoconsult No. 289 - 11 Januari 2002, Jakarta.

Krisnadewara, P.D., dan Sri Susilo, Y., 2003, "Survei Kinerja Koneksi Internet Warnet di Yogyakarta", Laporan penelitian, Fakultas Ekonomi UAJY, Yogyakarta. (Tidak Dipublikasikan)

Kuncoro, M., 2003, Metode Riset Untuk Bisnis \& Ekonomi: Bagaimana Meneliti \& Menulis Tesis, Erlangga, Jakarta.

Mas'udi, A., (2001), "Matinya Bisnis Warnet Kecil", Kolom Telematika, diakses dari www.detik.com pada tanggal 15 September 2002.

Sekaran, U., (2000), Research Methods for Business, $3^{\text {rd }}$ Edition, John Wiley \& Sons, New York.

Sugiarto, Siagian, D., Sunaryanto, L.T., Oetomo, D.S., (2001), Teknik Sampling, Cetakan 1, Gramedia, Jakarta.

Sugiyono, (2000), Metode Penelitian Bisnis, Cetakan Ke-2, Alfabeta, Bandung.

Suriadinata, Y. S. A., (2001), "Penelitian dan Penggunaan Teknologi Informasi dan Komunikasi oleh UKM Eksportir di Indonesia", Laporan Hasil Penelitian, ECG and PEG-USAID, diakses dari www.peg.or.id tanggal 25 Mei 2002. 